\title{
Racism: On the phenomenology of embodied desocialization
}

\author{
Michael Staudigl
}

Published online: 23 December 2011

(C) The Author(s) 2011. This article is published with open access at Springerlink.com

\begin{abstract}
This paper addresses racism from a phenomenological viewpoint. Its main task is, ultimately, to show that racism as a process of "negative socialization" does not amount to a contingent deficiency that simply disappears under the conditions of a fully integrated society. In other words, I suspect that racism does not only indicate a lack of integration, solidarity, responsibility, recognition, etc.; rather, that it is, in its extraordinary negativity, a socially constitutive phenomenon per se. After suggesting phenomenology's potential to tackle the question of racism, I will focus on the experiential oppressiveness of racism, i.e., the ways in which it affects its victims' lived experiences, in transforming their habitual ways of life and, finally, their subjectivities. My major thesis is that racism works via both interkinaesthetically as well as symbolically inflicted distortions of the victim's body schema. As such a process of "negative socialization," racism, however, influences the embodied self-conception of the oppressor, who finds himself compelled to adhere to some kind of invisible norm such as, e.g., "whiteness."
\end{abstract}

Keywords Racism · Phenomenology - Embodiment - Symbolic Institution · Desocialization

\section{Introduction}

We had better courageously face the fact that prejudices are themselves elements of the interpretation of the social world and even one of the mainsprings that make it tick. Prejudices are rationalizations and institutionalizations of the underlying 'central myth' upon which the self-interpretation of the group is founded. It makes little sense to tell the Negrophobe in the 
South that in terms of biological science there is no such thing as a Negro race. ${ }^{1}$

What makes Schutz's insight, which he formulates in his 1955 essay "Equality and the Social Meaning Structure," philosophically remarkable is that it not only considers the negativity of a specific type of social action with unusual acuity, but also recognizes such negativity as the social action's very "mainspring." With this in mind, in this paper, I seek to analyze "racism" as a phenomenon of "negative sociality" and, thereby, to view it from a socio-phenomenological perspective. Such a project requires three crucial preliminary considerations. First, it is necessary to reflect on what I understand by "negative sociality." Second-taking into account the insights of more recent studies-I will foreground what I do not want to understand by racism. In the light of these reflections, it should become clear from the outset why I view racism as an exemplary phenomenon of "negative sociality." Third, I will address, in brief, why I consider phenomenology suitable for an analysis of racism as being such a phenomenon.

Following these preliminary considerations, in the main section of my paper, I will turn to the analysis of the phenomenon itself. In doing so, I am not concerned, however, with tracing the concrete historical manifestations of racism. Rather, my analysis will center on, to my mind, the invariant methods, which characterize racism as a specific form of social practice (or "social technology") that exploits our dependency upon bodily identifications. Following Hund, these methods could be aptly described as "negative socialization," 2 which are of identity-relevance not only for those subjected to them, but also for those that "employ" them. Drawing on concrete phenomenological descriptions, I aim to exhibit these methods by way of examples, two of which I shall focus on.

In the concluding section, I seek to clarify, at least in outline, whether and to what extent racism can be understood as an irreducible phenomenon of "negative sociality" and how such an understanding of racism bears on the way in which it is dealt with socially.

\section{Three preliminary considerations}

(a) The expression "negative sociality" appears, at first, eminently problematic. Indeed, it seems to speak directly to the suspicion "that [...] negative experiences [such as mistrust, discrimination, contempt, or violence] cannot be cancelled out by a community or a society that is characterized by responsibility, justice, and recognition." If this were the case, then we would be faced with the necessity fundamentally to revise these concepts, and eventually even the concept of the social itself. For according to the thesis deduced thereof, the social, under these conditions, can "not be

\footnotetext{
1 Schutz (1976, p. 272).

2 On this concept see Hund (2006).
} 
consistently brought under the rule of law or be pacified by the rules of coexistence." 3

From this follows that the focus must rest on negativity-i.e., concretely lived "negative experiences"-in terms of its irreducibility or indissolubility in "social life" itself and on the coherence and intelligibility related to it. Thus the term "negativity" does not refer to a phenomenon of contingent deficiency that could be caught up with discursively, mediated dialectically, or overcome procedurally - to name but a few approaches to coping with contingency. Negativity does not merely amount to a contingent deficiency of justice, trust, responsibility, communalization, solidarity, communication, and so on, as tends to be assumed by the mainstream of social philosophy, where it is at all sensitive to this issue. Whether a philosophical perspective assumes that such "negative experiences" can be countered by a unity that is to be realized through harmony, universality, concordia, homonoia, the "reciprocity of perspectives," the "non-violent discourse," or the "ideal communication society," whilst a political perspective opposes them to the ideals of a fully integrated society or an organic community, under the unifying force of which such negativity should simply dissolve: In all these cases, negativity is presented as relative, as pure deficiency or as an "exception in social functioning," 4 i.e., as "socially anomalous, as unusual, an individual aberration or institutional hangover." 5

In contrast, I suggest that it is indeed necessary that negativity be understood as a "factum" in the sense of the Kantian "factum of reason," which cannot be sublated into a more comprehensive legal or political order. It cannot be sublated because it is extraordinary in respect to this order. To conceive of negativity in its extraordinariness, however, also entails a reflection on its order-constitutive function. For orders (re)generate through exclusion and selection-through the production of an extraordinary. Thus, just as there is order, there is also violence. In particular, there is the violent character of order itself, to the extent to which it always functions on a selective and exclusive basis, i.e., to the extent to

\footnotetext{
3 This approach is proposed by Hetzel, Liebsch and Sepp in their introduction to a forthcoming volume on "Profile negativistischer Sozialphilosophie."

4 Terkessidis (2004, p. 8).

5 Goldberg of course critically opposes this view: "The prevailing view concerning contemporary racism is that it is something that belongs to the past. Where it is taken to occur at all, it is considered as socially anomalous, as unusual, an individual aberration or institutional hangover placed in check as soon as its occurrence is noticed. Anyone extending to racist expression a greater place in contemporary culture than this picture warrants is bound to be considered paranoid-or (as the current charge would have it) politically correct" (Goldberg 1993, p. viii).
} 
which it excludes the extraordinary by including it. ${ }^{6}$ Thus, within order there inheres a constitutive moment of negativity. This moment, however, is not contingent because it renders possible the order's accomplishment of order (and therefore provides identity-relevant motivations to act). Therefore, it is imperative to recognize that in its extraordinariness and indissolubility, negativity plays a constitutive role for the accomplishment of social order-and thus concretely for socialization. This implies that the aforementioned phenomena of "negative sociality" are, on the one hand, social phenomena through and through, while, on the other, they negate the facticity of the social in-between, the horizon within which we tend to think. Phenomena of "negative sociality" bear de-socializing effects and remind us of the limits of socialization and communality, ${ }^{7}$ whilst at the same time remaining socially overdetermined and tied to concrete social action in their effectiveness.

(b) For a considerable time, research on racism has attempted to demonstrate that it would be more felicitous to speak not of racism, but of racisms. ${ }^{8}$ As shown by several analyses, the reference to the concept of "race" is by no means constitutive for the historical manifestations of racism. Rather, the differentiation of this concept is married to diverse social-historical contexts; as a consequence, "race" has to be viewed as a "social construct." 9 At the same time, the opposite view has been put forth arguing for a "racism without races," 10 i.e., a racism that succeeds culturalistically without any longer requiring the concept of race to this end. As a result of these insights, a distinction has consistently been drawn between racisms of "race," and those within class, gender, and nationality, ${ }^{11}$ which on their part rely on ideological, religious, or culturalistic discourses of legitimization. At stake in all these

\footnotetext{
6 This point concerns the self-preservation of factual order in terms of apparently legitimate violence against the imminent threat of disorder, i.e., by invoking a generic gap-or even a mythic strugglebetween rationality and violence. Waldenfels explains this as follows: "By stigmatizing the criminal as pure malfeasant, the political rebel as pure criminal, the enemy as 'underman,' or underdog, a good conscience is preserved in a society that nolens volens does violence to others. The representatives of society defend themselves, refusing even answers to their enemies. The law creates 'outlaws' without questioning what kind of 'out' this is. The justification of violence is compensated for by the selfrighteousness of reason, which cedes to its own violence the more this process is disguised by rationalization" (Waldenfels 1991, p. 108). For a more detailed account on the selective and exclusionary functions of order, see Bauman (1991) and Waldenfels (1996).

7 An early reflection on the "limits of community" is provided by Plessner (1999).

8 Already since the 1970 s, such a plurality has been acknowledged by researchers such as Stuart Hall, Etienne Balibar, Robert Miles, Patrick Girard, and others. For an excellent overview, see Garner (2009).

9 See the exemplary discussion in Banton (1998, pp. 196-235). Amongst the first ones to clearly state this idea, Omi and Winant (1986, pp. 61-68) developed a "theory of racial formation" that "emphasizes the social nature of race, the absence of any racial characteristics, the historical flexibility of racial meanings and categories, the conflictual character of race at both the 'micro-' and 'macro-social' levels, and the irreducible political aspect of racial dynamics" (ibid., p. 4).

${ }^{10}$ Balibar and Wallerstein (1991, p. 21).

11 See, e.g., Hund (2007, pp. 15-20). In this article, I will not touch upon the crucial question whether these distinctions result in a conceptual inflation of the concept of racism.
} 
cases, there is-and at least until here, the minimum consensus seems to reach-"a process of the social construction of purportedly natural inequality," which is an attempt "to find a natural explanation for social differences." 12 As a hegemonic scheme of explanation, racism therefore always also mirrors the power relations that shape the integrity of societies internally and externally. In contrast to social discrimination, which "structures individuals within the social context according to hierarchical contrasts," racism-taken in the broadest sense-posits these individuals "as others outside of the social context, in robbing them of their social particularity, or denying their ability for it." ${ }^{13}$ In this vein, racism functions as a motive or a means of threat for social integration or exclusion on the one hand, and assimilation or segregation on the other. This dual direction of the impact of racist processes of socialization, which as a result works on the basis of a dual logic of "including exclusion" and "excluding inclusion," is- to my mindconstitutive for the phenomenon.

In accordance with what has been stated so far, I understand racism as a social process of hetero-normative meaning-constitution, ${ }^{14}$ which holds out the prospect of an illusory sense of community through bodily desocializing others and thus charts identity-relevant motivations for actions for those who seek to belong to this imagined community. What vary in the history of racism are the legitimization patterns of these processes and the practices of exclusion that substantiate them. It may therefore be the case that "ideal-typical constructions" fail to grasp the diversity and heterogeneity of racist practices. They do seem comparable, however, insofar as they "construct the others"-within society as well as outside of it_- "as deficient beings and locate them beyond all respective social dualisms." 15 From this insight follows moreover that

[t]he achievement of identity at the expense and to the detriment of others does not only generate different degrees of being human, but also destabilizes the very context that it founds. At the same time as the border to inferiority is maintained outwardly, it is drawn into the very inner of society in form of a flexible predetermined breakage point. ${ }^{16}$

Thus it follows that as a form of "negative socialization," racism must be viewed as an exemplary phenomenon of negative sociality because it is not only a negating social practice, but also makes us aware of the negativity of the social itself, i.e., the social violence that is an integral part of its constitution.

(c) Can phenomenology, then, make a contribution to an analysis of racism as a process of "negative socialization" — an undoubtedly historical process, into

\footnotetext{
12 Hund (2007, p. 35), see Delacampagne (2005, p. 60).

13 Hund (2006, p. 124).

14 I take the concept of "heteronormativity" from the context of gender studies, see esp. Ingraham (1994).

15 Hund (2006, p. 124).

16 Hund (2006, p. 123).
} 
which flow concrete material foundations, structural forms of social organization, and ideological justifications? On the assumption that racism, or to speak with R. Miles, "racializations" are in many cases processes of "meaning-constitution" 17 that are transmitted on a pre-reflexive level and that carry with them identity-relevant choices of identification or experiences of exclusion, a phenomenological-or, more precisely, a socio-phenomenological-approach to analysis seems fitting. A closer look reveals two reasons supporting my assertion. The first concerns the specificity of the subject matter-violence or a relation of violence-, the second relates to the specific methodology of phenomenological analysis.

1. The practice of phenomenology allows for what, following Husserl, we could designate as an "ethical epoché." 18 I understand the task of such an epoché to be the bracketing of all those discourses on the reasons and the justifications of violence, in the normatively overdetermined (and oftentimes moralizing) light of which the analysis of direct violence and indirect relations of violence-both implied by racism-has to a large extent taken place hitherto. Thus, phenomenology must seek to thematize the conditions of possibility of violence and relations of violence; it must focus on what is responsible for rendering such-in this case racistviolence possible in the first case, and must ask how what is identified can then subsequently become the subject of discourses of justification. ${ }^{19}$ In this, it emerges as necessary that a phenomenology of racist violenceand respectively, a phenomenology of violence in general-get to the bottom of those processes of desensibilization that precede all direct violence. Focusing their structure, pre-reflective functioning, and genesis, a phenomenology of violence intends to show how subjects grow indifferent to the suffering of others, and that they can hence no longer perceive the singularity of their "ethical demand." 20

2. Here, the second reason for my choice of the phenomenological approach becomes perspicuous: it is the only approach that is in a position to steer clear of the nominalistic and essentialist misinterpretations of the phenomenon, in order to trace, conversely, the effective reality of racializations in the everydayness of lived experience, personal habitualities, and the institutions of our life-world. ${ }^{21}$ This implies, more concisely, that so-called "meaning-constitutions" can be comprehensively

\footnotetext{
${ }^{17}$ In his works on racism as social practice and ideology, Robert Miles has focussed on the various interconnected "processes of signification and representation" that constitute "race" as a social attribution (see Miles 1989, pp. 69-98).

18 Husserl (1959, p. 319).

19 On the issue of the ambiguity of the legitimization of violence see Waldenfels (1991).

20 As has been shown by Levinas in his essay "Useless Suffering," the reason for this lies in an ontologization of violence, which defines violence as an "ontological perversion" because of its inevitability — which, however, by no means excludes its minimization-as well as likening it to "the useless suffering that springs from natural plagues" (Levinas 1998, p. 95). As regards collective violence, I provide an account of this process of desensibilization in Staudigl (2011).
}

21 See Alcoff (2005, pp. 173-194). 
reconstructed neither in reference to the motives of a self-reflective subject capable of acting instrumentally nor in taking recourse to structures by which actions are functionally governed. Rather, I would suggest, the focus must lie on those pre-reflective dimensions of lived experience that predetermine the habitus of our experiencing, and interactions in a bodily manner-i.e., in this context, which permeate it with racism or, more precisely, "racialize" it and, hence, make overt racist violence possible. Thus in terms of methodology, I consider the phenomenological approach suitable insofar as it admits for the illumination of the interplay between different registers of experience in their identity-relevance. Without elaborating this thought any further here, I propose to understand the meaning-constitution and therefore subject-constitution as the interplay between subjective sense-bestowal, anonymous processes of senseformation, and symbolic institution. The "open and indefinite unity of subjectivity" thus emerges, to follow Merleau-Ponty, in correlation with the "open unity of the world," the "autochthonous significance" 22 of which essentially determines its genesis. In viewing meaning-constitution and self-constitution as such a relational and basically inter-corporeal occurrence, a phenomenology thus transforms into a theory of culture on its own accord. Ultimately, it is only in the latter's light that phenomenology is able to zoom in adequately on the efficiency previously mentioned, i.e., on the performative force and apparent magic of culturally overdetermined nexuses of sense, and respectively, of hegemonic regimes of sense-formation (such as the concept of race or the pseudo-scientific discourse on race). ${ }^{23}$

\section{On the phenomenology of racist "methods"}

Thus, the direction of the impact of a phenomenological recourse to lived experience is clearly determined. Yet, does it not, in the same gesture, confront us with a dire problem? Does it not delineate a phenomenology that can no longer rely on the undeniable meaningfulness of the social world, but rather encounters the incompossible, the resistance of which undermines the "sheltering canopies" of our "symbolic universes" 24 ? Do not at least two mutually irreducible starting points of a reflection on the sense of violence offer themselves to such a pursuit? Whose experience is at stake here? Is it not either a "phenomenology of the oppressor" 25 as Sartre proposed, or a phenomenology of "suffered violence," hence a

\footnotetext{
22 Merleau-Ponty (2009, pp. 473, 512).

23 This is not the place for me to further develop the here mentioned phenomenological theory of culture, which I believe to hinge on the concept of "symbolic institution" (institution symbolique). The works of Marc Richir offer a systematic meditation on this potential of phenomenological research (see esp. Richir 1988; Tengelyi 2007).

24 See Berger and Luckmann (1966, p. 120).

25 Sartre (1992, p. 561).
} 
phenomenology of the experience of the victim of racist discrimination or violence? And matters seem to get even more complicated: From a phenomenological standpoint, are we not required also to consider the perspectives of a third party, be it actual (such as witnesses, followers, bystanders, "uninvolved observers") or virtual (for instance, one's conscience as the "innermost form of otherness," or the apparent universality of the law). For after all, the third party's presence or absence and intervention or passivity is, without doubt, of decisive importance for the genesis of the respective contexts of experience and their identity-relevant implications. To sum up my argument: Is the category of sense-the category of phenomenology and hermeneutics - at all suitable to cope with the structural difference, which patently seems to separate violence as an intention and violence as an experience that befalls us (to refrain here from a discussion of violence as a "second-order construct")? ${ }^{26}$

Despite the irreducibility, on which it insists, this problem appears to me to be only a pseudo-problem. For "the experience of the other"-to use a Husserlian concept-is relational through and through; social phenomena are "phenomena of the in-between," to use the language of Bernhard Waldenfels. The experience of the other is endowed with a sense, which "occurs between me and the other, between what is my own and what is foreign to me." More precisely, it possesses a sense, which can "neither be fully traced back to the initiative and the capacity of single individuals or groups nor to a mediating authority of order nor to codified regulations." 27 To put it phenomenologically, it possesses a sense, which can neither be entirely ascribed to the ego's sense-bestowals nor explained as the result of processes of "symbolic institution." Neither is it a sense that emerges completely behind the back of the active I. Rather, for its identity-relevant articulation, this sense requires the transition through the historic-cultural "interworld" of human symbolisms as well as the creative "re-ordering of fact and hazard." 28

In other words, the experience of the other thus bears a sense that is only articulated in the concrete intersubjective encounter, even though in this case-and this point is crucial-it does not indicate a "reciprocity of perspectives," which would secure for us at least a minimal access to a shared world. On the contrary, it is the concrete modality of racist practices, the mode in which it "addresses" others, which precludes this possibility, i.e., de-subjectivizes, de-humanizes the other.

With great force, Frantz Fanon gives voice to this experience of de-subjectivized subjectivization in the chapter "The Fact of Blackness" of his book Black Skin, White Masks. To my mind, this is, in fact, one of the first times that the problem of racism is described phenomenologically. Although it rests essentially on Sartre's

\footnotetext{
${ }^{26}$ On the here emerging difference between action-theoretical and definition-theoretical approaches, see Hitzler (1999).

27 Waldenfels (2002, p. 174).

28 On this "interworld," see Merleau-Ponty (1973, p. 200); on the "re-ordering," which demonstrates that conscious acts are never causally conditioned, but always "motivated," see Merleau-Ponty (2009, p. 147).
} 
theory of a bodily being-for-others, ${ }^{29}$ Fanon, at the same time, also seeks to do justice to the basic existential factum that is masked by Sartre: For the black man, the white man is not simply "only The Other but also the master, whether real or imaginary." "Not only does the concrete failure of the dialectic of recognition that is constitutive for Sartre's approach become manifest thereby; with Fanon, further, we are in the position to demonstrate that in the form of symbolically instituted power-relations, this factum informs the habitus of bodily self-experience of the "racialized objects" 31 and is thus performatively reproduced.

The black man among his own in the twentieth century does not know at what moment his inferiority comes into being through the Other... (...) And then the occasion arose when I had to meet the white man's eyes. An unfamiliar weight burdened me. The real world challenged my claims. In the white world the man of color encounters difficulties in the development of his bodily schema. Consciousness of the body is solely a negating activitiy. It is a third person consciousness. The body is surrounded by an atmosphere of certain uncertainty. I know that if I want to smoke, I shall have to reach out my right arm and take the pack of cigarettes lying at the other end of the table. (...) And all these movements are made not out of habit but out of implicit knowledge. A slow composition of my self as a body in the middle of a spatial and temporal world-such seems to be the schema. It does not impose itself on me; it is, rather, a definitive structuring of the self and the world—-definitive because it creates a real dialectic between my body and the world. ${ }^{32}$

Following Fanon, the "body schema" that is referred to here, which MerleauPonty thematized as the linchpin of the being-for-the-world mentioned earlier, describes a merely superficial mode of experiencing lived embodiment. What Fanon designates as the "historico-racial schema" underlies and structures it:

For several years certain laboratories have been trying to produce a serum for "denegrification;" with all the earnestness of the world, laboratories have sterilized their test tubes, checked their scales, and embarked on researches that might make it possible for the miserable Negro to whiten himself and thus to throw off the burden of that corporeal malediction. Below the corporeal schema I had sketched a historico-racial schema. The elements that I used had been provided for me not by "residual sensations and perceptions primarily of a tactile, vestibular, kinesthetic, and visual character," but by the other, the white man, who had woven me out of a thousand details, anecdotes, stories.

\footnotetext{
29 As Sartre sums it up: "I exist my body: this is its first dimension of being. My body is utilized and known by the Other: this is its second dimension. But insofar as I am for others, the Other is revealed to me as the subject for whom I am an object. Even there the question [...] is of my fundamental relation with the Other. I exist therefore for myself as known by the Other-in particular in my very facticity. I exist for myself as a body known by the Other. This is the third ontological dimension of my body." (Sartre 2000, p. 351).

30 Fanon (1986, p. 138, note).

31 In this distinction, I am following Toni Morrison (1992, p. 90) who speaks of "racial subjects" and "racial objects."

32 Fanon (1986, pp. 110-111).
} 
I thought that what I had in hand was to construct a physiological self, to balance space, to localize sensations, and here I was called on for more. ${ }^{33}$

The body schema as thematized by phenomenology seems, in this regard, to be the schema of a body that is in the world with-itself, a body that lives in a pre-reflexive balance with its surroundings, a body whose habitual performance knowledge is lived unproblematically. The "white gaze" (which is, of course, never merely a gaze nor simply white) racializes this schema. More precisely, it makes the one who is gazed at aware that the schema was always already racialized. As a consequence, his orientation in the world becomes questionable, the accessibility of certain objects seems suddenly problematic, and-more generally-the body schema breaks down to give room to a "racial epidermal schema." 34 This schema forces itself upon the perception of the social space and its institutions and organizes action in the light of a "retrospective reoccupation of a space that I already inhabited." 35 The lived space as such becomes white, in the sense of that "absent centre against which others appear only as deviants, or points of deviation." 36 The habitual incorporation of lived space re-oriented in this vein thus creates "habit worlds" and leads to the "institutionalization of a certain 'likeness,' which makes non-white bodies feel uncomfortable, exposed, visible, different, when they take up this place." 37 The "habitual body" 38 thus becomes the playing field for "symbolic violence," i.e., a violence that functions on basis of the pre-reflective embodiment of oppressive social power relations. Precisely because of its pre-reflexivity, it is, however, not conceived as violence, but rather succeeds in appearing as "naturally given.",39

I could no longer laugh, because I already knew that there were legends, stories, history, and above all historicity, which I had learned about from Jaspers. Then, assailed at various points, the corporeal schema crumbled, its place taken by a racial epidermal schema. [...]

I was responsible at the same time for my body, for my race, for my ancestors. I subjected myself to an objective examination, I discovered my blackness, my ethnic characteristics; and I was battered down by tom-toms, cannibalism, intellectual deficiency, fetichism, racial defects, slave-ships, and above all else, above all: "Sho' good eatin." [Y a bon banania $]^{40}$

The reflection on the so-called factum-i.e., on racism as a symbolically transmitted and reproduced relation of domination that generates patterns of

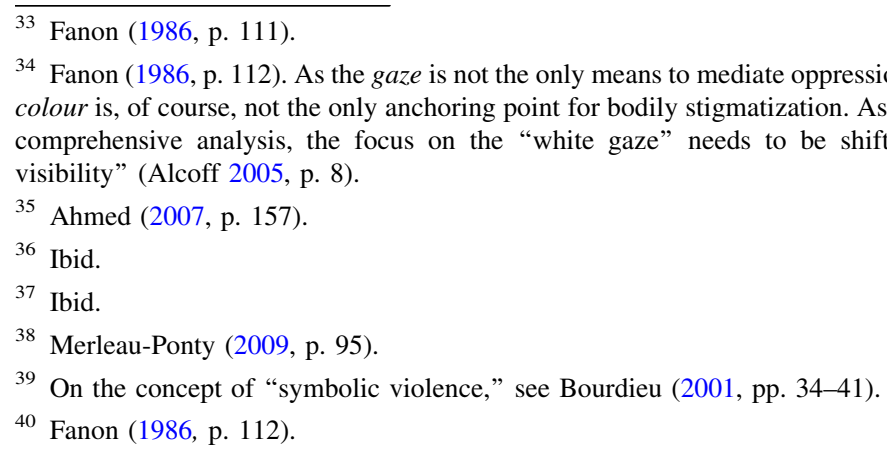


interaction prone of violence-therefore brings something else to the fore, something on which anti-racist discussions would only later begin to focus: the insight that in correlation to the "symbolic violence" of racism mentioned already, i.e., correlative to the symbolically embodied pre-formation of subjective action, the room to maneuver for the interaction of the "racialized subjects" undergoes a preformation too. ${ }^{41}$ Sartre became aware of this correlation subsequent to his first visit to the USA in the year 1945, when he began to reflect upon the "invisibility of the black gaze," 42 a gaze that was unable to enter into the struggle for recognition at all. Sartre realized that this imposed and habitually lived invisibility correlatively required an effort on the part of those that were completely absorbed by "whiteness as norm," 43 whilst constantly living in fear of not meeting this norm ${ }^{44}$-a fear which, as a consequence, became projected onto the Other. ${ }^{45}$

“Look, a Negro!" It was an external stimulus that flicked over me as I passed by. I made a tight smile.

"Look, a Negro!" It was true. It amused me.

"Look, a Negro!" The circle was drawing a bit tighter. I made no secret of my amusement. "Mama, see the Negro! I'm frightened!" Frightened! Frightened! Now they were beginning to be afraid of me. I made up my mind to laugh myself to tears, but laughter had become impossible. ${ }^{46}$

By focusing on the "lived experience of blackness," Fanon's descriptions also provide decisive starting points for an analytics of the "racist subject." It does so in proffering evidence that "the Negro, because of his body, impedes the closing of the postural schema of the white man" 47 - which characterizes him as "the principle of evil" 48 (of bad, impure, biological, sexual, etc.). Analogously, and in addition to the central modalities of the experience of racism, his descriptions also enable us to trace the central methods of racism, methods that have also been unearthed by comparative historical studies. ${ }^{49}$ First, we come upon the experience of inferiorization through the attribution of cultural difference. Such attribution practices employ a logic of mutual exclusion that is expressed in pairs of opposites such as

\footnotetext{
41 This also corresponds to Sartre's approach in his Critique of Dialectical Reason, where Sartre employs the concepts of the practico-inert and of seriality to thematize the responsibility-even the "categorical imperative" (Sartre 1976a, p. 303, note)—of being-white.

42 See Sartre (1945); on this in more detail Bernasconi (1995).

43 See David (2001), who draws the connection between this "norm" of whiteness (ibid., p. 167) and the metaphysics of "form," which for occidental philosophy leads to the following decisive question: "Comment voire cela, la 'couleur,' comment accéder au fait que la lumière n'est pas lumen naturale, lumière naturelle, mais lumière blanchie ?" (Ibid., p. 168).

44 See, on the motif of anxiety, Stokes, who analyzes being-white as a "form of textual, political, and sexual anxiety" (Stokes 2001, pp. 158-177); see also Dyer (1997, p. 44-45).

45 See for instance Young (1996). On the psychoanalytic motif of projection, see Fanon (1986, chapter 6); a systematic explication can be found in Kearney (2003).

46 Fanon (1986, pp. 111-112).

47 Fanon (1986, p. 160).

48 Fanon (1986, p. 190).

49 Hund (2007, pp. 82-119).
} 
culture/barbarism, civilization/savageness, purity/impurity, chosenness/fallenness or significance/inferiority. ${ }^{50}$ This process of an inferiorizing positing of difference represents a heteronormative form of socialization, which is ultimately based not on-an always discriminating-inclusion, but in principle on segregation and exclusion, i.e., it proceeds merely negatively. Secondly and closely linked to this is the resulting experience of self-alienation, which can be traced back to desocialization in principle as the objective inherent to inferiorization. ${ }^{51}$ The alienating splitting of consciousness, i.e., the "doubling of personality" according to Sartre or the "double consciousness" in the sense of Du Bois, ${ }^{53}$ results from the selfdenigrating adoption of racist norms the fulfillment of which is impossible by definition. The corresponding practices of desocialization are widespread and range from the "denial of social particularization" to a fundamental "questioning of cultural singularity." 54 Finally and most crucially, Fanon makes us aware of stigmatizing forms of embodiment that render possible and transmit desocialization and inferiorization, and which thus must be retained as the third central method of racism.

What has been said so far can, however, by no means only be demonstrated in the context of the "infernal machine" of colonialism, ${ }^{55}$ which is, of course, of decisive importance-from a historical perspective, for the genesis of a racial racism and from a genealogical perspective, for subsequent national racism. ${ }^{56}$ Rather-to take a big leap-we could say that it also becomes manifest in the affective micropractices of everyday racist interactions. To illustrate this point, I will refer to Audre Lorde's - practical-phenomenological-description of such an affectively overdetermined situation of interbodily encounter in her Sister Outsider:

The AA subway train to Harlem. I clutch my mother's sleeve, her arms full of shopping bags, christmas-heavy. The wet smell of winter clothes, the train's lurching. My mother spots an almost seat, pushes my little snowsuited body down. On one side of me a man reading a paper. On the other, a woman in a fur hat staring at me. Her mouth twitches as she stares and then her gaze drops down, pulling mine with it. Her leather-gloved hand plucks at the line where my new blue snowpants and her sleek fur coat meet. She jerks her coat closer

\footnotetext{
$\overline{50}$ See Hund (2007, pp. 121-126).

51 If inferiorization à la limite is geared towards desocialization, then the distinction between two "logics of racism," a debasing ("inequality-based") racism, on the one hand, which seems to be confined to the legitimization of economic and social inequalities, and a differentiating ("difference-based") racism, on the other, which relies on a mystical positing of differences beyond such discourses of legitimization (see Wieviorka 2005, pp. 42-45), is not tenable in regards to inferiorization's potential violence. Following Levinas, in contrast, one could say that all violence, hence also merely exclusive violence, is always "at the limit of murder" (Levinas 2007, p. 225).

52 Sartre (1976b, p. 104).

53 Du Bois (2007, pp. 8-9); he also speaks about a "double self" as well as a "double life" (ibid., p. 136).

54 Hund (2007, pp. 88-89).

55 This expression can be found in Sartre's analysis of the colonial system in his Critique of Dialectical Reason (Sartre 1976a, pp. 715-717); on the thereby mentioned "system of violence," see de Warren (2004, pp. 47-49).

56 On the here mentioned genealogy of National Socialism, see the decisive analysis by Traverso (2003).
} 
to her. I look. I do not see whatever terrible thing she is seeing on the seat between us - probably a roach. But she has communicated her horror to me. It must be something very bad from the way she's looking, so I pull my snowsuit closer to me away from it, too. When I look up the woman is still staring at me, her nose holes and eyes huge. And suddenly I realise there is nothing crawling up the seat between us; it is me she doesn't want her coat to touch. The fur brushes my face as she stands with a shudder and holds on to a strap in the speeding train. Born and bred a New York City child, I quickly slide over to make room for my mother to sit down. No word has been spoken. I'm afraid to say anything to my mother because I don't know what I have done. I look at the side of my snow pants secretly. Is there something on them? Something's going on here I do not understand, but I will never forget it. Her eyes. The flared nostrils. The hate. ${ }^{57}$

In this description of an intercorporeal encounter, the above mentioned methods of racism can be found again. Moreover, it exhibits with particular clarity how interpersonal encounters unfold in a medium of "interkinesthetic affectivity," 58 a dimension of lateral sense-formation that is rarely accounted for in mainstream social theory as well as in philosophy.

This becomes clear, first, with regard to the experience of inferiorization through the attribution of difference, which, in this case, occurs through the "misperception of a phobic object." 59 It is Audre herself who becomes this object-she experiences being the disgusting cause of the hatred that she meets in the other's gaze. Second, this leads to the experience of self-alienation, an experience, in this case, of an "I can not," which influences the lived "organization of social and bodily space." Since in this experience, the social space itself undergoes a change and is even affectively reconstituted, practices of desocialization come to the fore, which take shape in the "expulsion of Blackness from white social space" and correlatively in a "re-forming [of] the apartness of the white body." 60 Thereby, a stigmatizing mode of embodiment gains ground. For the affective over-determination of the encounter, which is described as unforgettable, does not merely call into question the ways Audre inhabits the lived space and coincides with the "ease of movement" of her body. Rather, it interferes with the body schema, by creating "disoriented bodies" the movement of which becomes a "defensive posture" in the social space, which is geared at avoiding "social stress" - and precisely thereby reproduces that same affective racist economy, which signalizes its exclusion from this space.

Summing up, I want to emphasize clearly once again that the "racialization" of identities through the said methods functions on two planes. Not only does it concern the discursive status of the subject in public, where it is rendered quasi "invisible" as a social agent, ${ }^{61}$ in order to secure thereby the normalizing

\footnotetext{
57 Lorde (1984, pp. 147-148). Concerning the discussion of this passage I rely on various insights provided by Ahmed (2004).

58 On this concept see Behnke (2008).

59 Ahmed (2004, p. 33).

60 Ibid.

61 See on this, in more detail, Bernasconi (2000).
} 
"invisibility" of the dominant identity-formation. Further, it bears especially on the manner of bodily self-experience of the subject. As a result of the subject's stigmatizing embodiment, its self-experience is haunted by "difficulties in the development of [the] bodily schema," 62 whilst our "I can" is usually, to put it with Sartre, "the neglected, "passed by in silence.",63 The "historical-racist schema," that comes to overlay the body schema, ${ }^{64}$ thus produces a habitus that seems to carry the stigma of difference, which is mediated discursively, always already inscribed into it: Regardless of whether this difference is taken up affirmatively and thus performatively reproduced, or whether it is discarded as objectively non-existing, to be evoked as an even more dangerous, for invisible danger-as difference, it is powerfully reflected in the amputated body schema, as Fanon describes it, or in the "inner overdetermination" of the actions of the racially dominated, to which Sartre refers in his "Anti-Semite and Jew." 65

In a nutshell, in light of the examples mentioned, racism can be grasped as the bodily inferiorization of the other which practices à la limite the Other's desocialization. Its "social sense" consists, besides, in imagining community and creating individual identity-offers, which pretend to transcend the contingency of factual forms of subjectivity, whilst effectively securing given power relations.

\section{Conclusion}

Current research has often underlined the structural character of racism, which, as it seems, can be abolished neither through a social critique nor through the intensified combat against ideological forms of prejudices and discriminations. In this context, Winant speaks of a "common-sense [...] feature of everyday life and global social structure." 66 From a structural-functional perspective, Hund emphasizes its integrating "function in the process of class-specific socialization." ${ }^{67}$ Goldberg makes the simple and disillusioned statement: "Race is irrelevant, but all is race."

Even if all "racist ideologies" could be abolished, racism, it follows, would by no means be disposed of once and for all. It appears to be an irreducible phenomenon of "negative sociality" as it settles into pre-reflectively lived schemata of perceptions, permeates the subjective system of relevance, and enters into the micro-practices of interaction (such as the posture or the gaze), in the daily reactivation of which it is tacitly reproduced.

\footnotetext{
${ }^{62}$ Fanon (1986, p. 110). nothingness and silence." (Ibid.).

${ }^{64}$ Fanon (1986, p. 112).

65 Sartre (1976b, p. 95).

${ }^{66}$ Winant (2001, p. 308).

${ }^{67}$ Hund (2007, pp. 120-121).
}

${ }^{63}$ Sartre (2000, p. 330). It is worth recalling the important context of this insight: "In short, consciousness (of) the body is lateral and retrospective; the body is the neglected, the 'passed by in silence.' And yet the body is what this consciousness is; it is not even anything except body. The rest is 
Of course, we could picture the social transformation of these practices. Yet, the question remains to which level these practices effectively reach. In this context, I have in mind not only the institutionalized or systemic forms, in shape of which a "racism against one's will" 68 characterizes also those societies in which but very few would explicitly understand or define themselves as racist and where, in contrast, the irrelevance of racializing identifications seems to prevail. Rather, I am thinking of the humanistic universalism, which demands the abolishment of such particularizing identifications and which, in doing so, fixes the selective normativity of its position, i.e., fixes the way the other is to appear in a world in which I do not need to thematize my identity precisely because it is an invisible norm. ${ }^{69}$ And finally, I have in mind in particular the "institutional desire for good practice," which almost teleologically glorifies the "social promise of diversity," with the result that "the desire for signs of resistance" changes all too rapidly into a "resistance to understanding racism as an ongoing and unfinished history."70

To conclude, the performative magic of racism is not only embedded into the meaningful constitution of the social world, i.e., into the "normal' societal functioning." 71 It finally returns in a "dialectics of equality and alterity" that haunts all our necessary attempts of a "comparison of the incomparable." 72 Insofar as the desire for identity and thus the identification of the Other is constitutive for this constitution, ${ }^{73}$ racism structurally inhabits it. As Levinas 'demonstrated,' "it is [indeed] obvious that it is in the knowledge of the other as a simple individual - the individual of a genus, a class, or a race-that peace with the other changes into hatred; it is the approach to the other as a "kind of this or that." "74 This reflection is important, but fails to provide us with an adequate demonstration of the reasons of such hate. From a phenomenological point of view, such hatred can be shown to be ignited by our anxiety to lose our grip on the other (in order to enable her to appear in her likeness) as well as the unsettling experience that we ourselves might not fit the norm of this "us". To show this, however, would be the task of another study.

Acknowledgments This article is part of my research project "The Many Faces of Violence," funded by the Austrian Science Fund (FWF, P 20300-G15). In addition to an anonymous reviewer at Continental Philosophy Review, I would like to thank Alina Vaisfeld for her accurate translation of this text as well as George Berguno and Joseph Lemelin for their critical remarks and help.

\footnotetext{
${ }_{68}$ Following the title of Weiß (2001), who uses Bourdieu's concepts of "symbolic violence" and of the "social space" to analyze racism as a symbolically mediated dimension of embodied desocialization.

69 As Hannah Arendt as well as Benny Lévy in his discussion with Sartre have argued, such an abstract universalism, which can indeed easily become an "instrument of racism," (Bernasconi 2000, p. 186) can, in turn, be countered by means of positive identifications. Both suggest thereby-amongst many othersthat everything else would lead to a "splitting of the self"- -but also to the return of racism. See on this issue also Berry (1995) and Williams (1997).

70 Ahmed (2007, p. 165).

71 Terkessidis (2004, p. 11).

72 I borrow this well-known expression from Levinas (1981, p. 158); on the here mentioned dialectic, which haunts even the most reflective "politics of difference," see the fundamental investigations by Michael Barber (2001, pp. 12-13).

73 This has been forcibly demonstrated by Wieviorka (2003).

74 Levinas (1999, p. 139).
} 
Open Access This article is distributed under the terms of the Creative Commons Attribution Noncommercial License which permits any noncommercial use, distribution, and reproduction in any medium, provided the original author(s) and source are credited.

\section{References}

Ahmed, Sara. 2004. Collective feelings. Or, the impressions left by others. Theory, Culture, Society 21(2): $25-42$.

Ahmed, Sara. 2007. A phenomenology of whiteness. Feminist Theory 8(2): 149-168.

Alcoff, Linda M. 2005. Visible identities, race, gender, and the self. Oxford: Oxford University Press.

Balibar, Etienne, and Immanuel Wallerstein. 1991. Race, nation, class. Ambivalent identities. London, New York: Verso.

Banton, Michael. 1998. Racial theories, 2nd ed. Cambridge: Cambridge University Press.

Bauman, Zygmunt. 1991. Modernity and ambivalence. Ithaca, N.Y.: Cornell University Press.

Barber, Michael D. 2001. Equality and diversity. Phenomenological investigations of prejudice and discrimination. New York: Humanity Books.

Behnke, Elizabeth. 2008. Interkinaesthetic affectivity: A phenomenological approach. Continental Philosophy Review 41(2): 143-161.

Berger, Peter L., and Thomas Luckmann. 1966. The social construction of reality. A treatise in the sociology of knowledge. London: Random House.

Bernasconi, Robert. 1995. Sartre's gaze returned: The transformation of the phenomenology of racism. Graduate Faculty Philosophy Journal 18(2): 359-379.

Bernasconi, Robert. 2000. The invisibility of racial minorities in the public realm of appearances. In Phenomenology of the political, ed. Kevin Thompson, and Lester Embree, 169-187. Dordrecht/ Boston/London: Springer.

Berry, Bernita C. 1995. 'I just see people'. Exercises in learning the effects of racism and sexism. In Overcoming racism and sexism, ed. Linda A. Bell, and David Blumenfeld, 45-51. Lanham: Rowman \& Littlefield.

Bourdieu, Pierre. 2001. Masculin domination (trans: Nice, Richard). Stanford: Stanford University Press.

David, Alain. 2001. Racisme et antisémitisme. Essai de philosophie sur l'envers de concepts. Paris: Eclipses.

Delacampagne, Christian. 2005. Die Geschichte des Rassismus. Düsseldorf: Artemis \& Winkler.

De Warren, Nicolas. 2004. The apocalypse of hope. Political violence in the writings of Sartre and Fanon. Graduate Faculty Philosophy Journal 27(1): 25-59.

Du Bois, William E.B. 2007. The soul of black folks in writings. Oxford: Oxford University Press.

Dyer, Richard. 1997. White. London: Routledge.

Fanon, Frantz. 1986. Black skin, white masks (trans: Markmann, Charles L.). London: Pluto Press.

Garner, Steve. 2009. Racisms. An introduction. London: Sage.

Goldberg, David T. 1993. Racist culture, philosophy and the politics of meaning. Malden, Oxford: Blackwell.

Hitzler, Ronald. 1999. Gewalt als Tätigkeit. Vorschläge zu einer handlungstypologischen Begriffsklärung. In Ordnungen der Gewalt: Beiträge zu einer politischen Soziologie der Gewalt und des Krieges, ed. Sighard Neckel, and Michael Schwab-Trapp, 9-19. Opladen: Leske + Budrich.

Hund, Wulf D. 2007. Rassismus. Bielefeld: Transcript.

Hund, Wulf D. 2006. Negative Vergesellschaftung. Dimensionen der Rassismusanalyse. Münster: Westfälisches Dampfboot.

Husserl, Edmund. 1959. Erste Philosophie (1923/24). Zweiter Teil: Theorie der phänomenologischen Reduktion. The Hague: Kluwer.

Ingraham, Chrys. 1994. The heterosexual imaginary: Feminist sociology and theories of gender. Sociological Theory 2: 203-219.

Kearney, Richard. 2003. Strangers, gods, and monsters. Interpreting otherness. London, New York: Routledge.

Levinas, Emmanuel. 1981. Otherwise than being or beyond essence (trans: Lingis, Alphonso). The Hague: Kluwer. 
Levinas, Emmanuel. 2007. Totality and infinity. An essay on exteriority (trans: Lingis, Alphonso). Pittsburgh: Duquesne University Press.

Levinas, Emmanuel. 1999. Peace and proximity. In Alterity and transcendence (trans: Smith, Michael B.). New York: Columbia University Press.

Levinas, Emmanuel. 1998. Useless suffering. In On-thinking-of-the-Other. Entre nous (trans: Smith, Michael B. and Harshav, Barbara), 91-101. New York: Columbia University Press.

Lorde, Audre. 1984. Sister outsider: Essays and speeches. Freedom: The Crossing Press.

Merleau-Ponty, Maurice. 1973. Adventures of the dialectic (trans: Bien, Joseph). Evanston: Northwestern University Press.

Merleau-Ponty, Maurice. 2009. Phenomenology of perception (trans: Smith, Colin). London, New York: Routledge.

Miles, Robert. 1989. Racism. London, New York: Routledge.

Morrison, Toni. 1992. Playing in the dark. Whiteness and the literary imagination. Cambridge: Vintage Books.

Omi, Michael, and Howard Winant. 1986. Racial formation in the United States. From the 1960s to the 1980s. London, New York: Routledge.

Plessner, Helmuth. 1999. The limits of community: A critique of social radicalism (trans: Wallace, Andrew). New York: Humanity Books.

Richir, Marc. 1988. Phénoménologie et institution symbolique (phénomènes, temps et êtres II). Grenoble: Millon.

Sartre, Jean-Paul. 2000. Being and nothingness. An essay on phenomenological ontology (trans: Barnes, Hazel E.). London, New York: Routledge.

Sartre, Jean-Paul. 1992. Notebooks for an ethics (trans: Pellauer, David). Chicago: University of Chicago Press.

Sartre, Jean-Paul. 1976a. Critique of dialectical reason. Theory of practical ensembles (trans: SheridanSmith, Alan). London: NLB.

Sartre, Jean-Paul. 1976b. Anti-semite and jew. An exploration of the etiology of hate (trans: Becker, George J.). New York: Schocken Books.

Sartre, Jean-Paul. 1945. Retour aux Etats-unis. Ce que j'ai appris du problème noir. In Figaro 16, Juni 1945.

Schutz, Alfred. 1976. Equality and the meaning structure of the social world. In Collected papers II. Studies in social theory, ed. Arvid Brodersen, 226-273. The Hague: Kluwer.

Staudigl, Michael. 2011. L'Europe et ses violences. Contribution à une généalogie phénoménologique des violences extrêmes. Revue philosophique de Louvain 109(1): 85-114.

Stokes, Mason. 2001. The color of sex. Whiteness, heterosexuality, and the fiction of white supremacy. Durham, London: Duke University Press.

Tengelyi, László. 2007. Kultur als symbolische Sinnstiftung. Versuch einer Begriffsbestimmung. In Aufklärungen durch Erinnerung, Selbstvergewisserung und Kritik, ed. Frauke Kurbacher, Karel Novotný, and Katrin Wendt, 93-102. Würzburg: Königshausen \& Neumann.

Terkessidis, Mark. 2004. Die Banalität des Rassismus. Migranten zweiter Generation entwickeln eine neue Perspektive. Bielefeld: Transcript.

Traverso, Enzo. 2003. The origins of Nazi violence (trans: Lloyd, Janet). New York: The New Press.

Waldenfels, Bernhard. 1991. Limits of legitimation and the question of violence. In Justice, law, and violence, ed. James B. Brady, and Newton Garver, 99-111. Philadelphia: Temple University Press.

Waldenfels, Bernhard. 1996. Order in twilight (trans: Parent, David J.). Athens: Ohio University Press.

Waldenfels, Bernhard. 2002. Bruchlinien der Erfahrung. Phänomenologie-Psychoanalyse-Phänomenotechnik. Frankfurt: Suhrkamp.

Weiß, Anja. 2001. Rassismus wider Willen. Ein anderer Blick auf eine Struktur sozialer Ungleichheit. Wiesbaden: VS-Verlag.

Wieviorka, Michel. 2003. Kulturelle Differenzen und kollektive Identitäten. Hamburg: Hamburger Edition.

Wieviorka, Michel. 2005. The arena of racism. London: Sage.

Williams, Patricia J. 1997. Seeing a color-blind future: The paradox of race (Reith Lectures, 1997). New York: Farrar, Straus and Giroux.

Winant, Howard. 2001. The world is a ghetto. Race and democracy since World War II. New York: Basic Books.

Young, Lola. 1996. Fear of the dark. 'Race,' gender, and sexuality in the cinema. London: Routledge. 